\title{
Particle Fluxes and Bulk Geochemical Characterization of the Cabo Frio Upwelling System in Southeastern Brazil: Sediment Trap Experiments between Spring 2010 and Summer 2012
}

\author{
ANA LUIZA S. ALBUQUERQUE ${ }^{1}$, ANDRÉ L. BELÉM ${ }^{1}$, FRANCISCO J.B. ZULUAGA ${ }^{1}$, \\ LIVIA G.M. CORDEIRO ${ }^{1}$, URSULA MENDOZA ${ }^{1}$, BASTIAAN A. KNOPPERS ${ }^{1}$, \\ MARCIO H.C. GURGEL ${ }^{2}$, PHILIP A. MEYERS ${ }^{3}$ and RAMSÉS CAPILLA ${ }^{4}$ \\ ${ }^{1}$ Programa de Geoquímica Ambiental, Departamento de Geoquímica, Universidade Federal Fluminense, \\ Outeiro São João Baptista, s/n, 24020-150 Niterói, RJ, Brasil \\ ${ }^{2}$ Escola de Artes, Ciências e Humanidades, Universidade de São Paulo, \\ Rua Arlindo Béttio, 1000, 03828-000 São Paulo, SP, Brasil \\ ${ }^{3}$ Department of Earth and Environmental Sciences, The University of Michigan, \\ Ann Arbor, 48109-1005, Michigan, United States \\ ${ }^{4}$ Centro de Pesquisas e Desenvolvimento Leopoldo Américo Miguez de Mello/CENPES, \\ Avenida Horácio Macedo, 950, Cidade Universitária, 21941-915 Rio de Janeiro, RJ, Brasil
}

Manuscript received on July 16, 2012; accepted for publication on May 9, 2013

\begin{abstract}
Physical and biogeochemical processes in continental shelves act synergistically in both transporting and transforming suspended material, and ocean dynamics control the dispersion of particles by the coastal zone and their subsequent mixing and dilution within the shelf area constrained by oceanic boundary currents, followed by their gradual settling in a complex sedimentary scenario. One of these regions is the Cabo Frio Upwelling System located in a significantly productive area of Southeastern Brazil, under the control of the nutrient-poor western boundary Brazil Current but also with a wind-driven coastal upwelling zone, inducing cold-water intrusions of South Atlantic Central Water on the shelf. To understand these synergic interactions among physical and biogeochemical processes in the Cabo Frio shelf, a series of four experiments with a total of 98 discrete samples using sediment traps was performed from November 2010 to March 2012, located on the $145 \mathrm{~m}$ isobath on the edge of the continental shelf. The results showed that lateral transport might be relevant in some cases, especially in deep layers, although no clear seasonal cycle was detected. Two main physical-geochemical coupling scenarios were identified: singular downwelling events that can enhance particles fluxes and are potentially related to the Brazil Current oscillations; and events of significant fluxes related to the intrusion of the $18^{\circ} \mathrm{C}$ isotherm in the euphotic zone. The particulate matter settling in the Cabo Frio shelf area seems to belong to multiple marine and terrestrial sources, in which both Paraiba do Sul River and Guanabara Bay could be potential land-sources, although the particulate material might subject intense transformation (diagenesis) during its trajectory to the shelf edge.
\end{abstract}

Key words: sediment traps, bulk geochemical composition, Cabo Frio Upwelling System, particle flux, Southeastern Brazilian shelf.

Correspondence to: Ana Luiza Spadano Albuquerque

E-mail: ana_albuquerque@id.uff.br 


\section{INTRODUCTION}

Continental margins play a key role in linking land and ocean as a pathway for the transportation and transformation of organic and mineral particles from diverse sources (Schmidt et al. 2010). Although the continental shelf represents only a small fraction of the total ocean area, its margins contain the estuarine, coastal, shelf, shelf-edge and shelf-slope realms, each of which are prone to great spatial and temporal variability in the distribution, transport, transformation and, ultimately, sedimentation of pelagic inorganic and organic particles. Coastal particulate materials are supplied by autochthonous sources, such as primary producers and associated biological carbonate formation throughout the trophic web, as well as allochthonous sources, such as continental run-off; coastal erosion; and coastal, shelf-edge and eddy upwelling and resuspension, supplying different mixes of nutrients and particles to the shelves (Mantoura et al. 1991).

Physical, chemical and biological processes act synergistically on both the transport and transformation of suspended particulates, affecting the geochemical bulk composition and density as well as altering the physical, chemical and biological particlewater interactions through different processes, including flocculation, aggregation, desorption and adsorption (Turner and Millward 2002). Ocean dynamics control the dispersion of particles by riverine plumes and their subsequent mixing and dilution within coastal and oceanic boundary currents, followed by their gradual sedimentation within the shelf area. All of these sources and processes operate according to their own temporal and spatial constraints, creating a complex scenario for understanding the origins and fates of suspended particles at the ocean margin and their fluxes to the ocean floor (Liu et al. 2010, Schmidt et al. 2010).

The magnitude and temporal variability of particle fluxes have been evaluated in different oceanic environments all over the world through the use of sediment traps (Honjo et al. 2008).
However, on the southwestern Atlantic margin, only a few studies have used this tool and then only in short-term experiments (Knoppers et al. 1996, Jennerjahn et al. 1999, 2010, Jennerjahn and Ittekkot 1999). Although the importance of these studies is irrefutable, there are still several open questions, mainly regarding how physical forcing and particulate fluxes are coupled and how climate forcing may seasonally affect the sources and fluxes of particles on the shelves.

One of the most productive areas of the eastern South American margin is the Cabo Frio Upwelling System (CFUS) (Jennerjahn et al. 2010). Despite its location on a passive margin under the control of the nutrient-poor western boundary current, the sea surface temperature and chlorophyll concentrations in the CFUS area reveal a dynamic, complex oceanographic system controlled by interactions among instabilities of the southward trajectory of the oligotrophic Brazil Current (BC) (Silveira et al. 2008, Belem et al. 2013), wind-driven coastal Ekman transport (Valentin 1984, Carbonel 2003, Castelao and Barth 2006), mid-shelf eddy-induced cold-water intrusion of South Atlantic Central Water (SACW) to the photic zone (Brandini 1990, Campos et al. 2000, Calado et al. 2010) and mid-shelf thermal fronts (Castro et al. 2008), leading to a heterogeneous pattern of primary productivity (Franchito et al. 1998, Lopes et al. 2006), recycling and transport of particulate material on the shelf. Understanding these synergic interactions among the physical and biogeochemical features in the CFUS is crucial to identifying particle sources and determining the extent of recycling or reworking as well as predicting whether the material will be deposited on the sea floor or exported to the deep ocean.

The importance of riverine inflow on the shelf has been neglected both as a stimulator of CFUS productivity and as a supplier of suspended particles. However, the role of the mediumsized mesotrophic Paraiba do Sul River (PSR) and plumes originating in the Guanabara Bay as potential sources of dissolved and particulate 
matter to the Cabo Frio shelf has been debated in the literature (Valentin et al. 1978, Kahler and Voss 1996, Knoppers et al. 1996, Oliveira et al. 2012), and it is still poorly understood. The aim of the present study is to provide insight into the variability of the total and organic particulate matter fluxes and sources on the edge of the Cabo Frio continental shelf Upwelling System and to investigate the mechanisms underlying the sources and transport of particles on the shelf. To assess these goals, two sediment traps in a fully equipped oceanographic mooring line were deployed from November 2010 to March 2012 on the $145 \mathrm{~m}$ isobath edge of the continental shelf of the CFUS. This experiment provided an unprecedented opportunity to collect data from moored sediment traps on the southwestern Atlantic margin for more than one year and allowed us to evaluate the impact of physical dynamics on biogeochemical processes.

\section{MATERIALS AND METHODS}

\section{OCEANOGRAPHIC SETTINGS}

The Cabo Frio Upwelling System (CFUS), located off the coast of Brazil, is unique on the southeastern continental margin because it is marked by a sudden change of the orientation of the coastline from north-south to east-west. The adjacent continental shelf and margin mimics the coastline orientation change in its geomorphological configuration (Figure 1A). Moreover, due to regional physiographic particularities, the Cabo Frio region can be considered an oceanographic, sedimentological and biological boundary, marked by the change of the axis of the Brazil Current (BC) and its geostrophic adjustment to the edge of the continental shelf south of Cabo Frio (Moreira da Silva 1973, Valentin and Kempf 1977). This region is also particularly well known for the occurrence of upwelling events focused on the Cabo Frio and Cabo de São Tomé coastal points, where the cold and nutrient-rich South Atlantic Central Water reaches the surface, while the offshore region is dominated by the $\mathrm{BC}$, which carries warm and nutrient-poor tropical water.

Northeasterly winds that favor upwelling predominate during spring and summer for long periods of days, which can be associated with surface cold-water events near the Cabo Frio coast (Franchito et al. 2008). However, the presence of South Atlantic Central Water (SACW) on the shelf enriches the water column with nutrients, significantly affecting the productivity of regional fisheries (Matsuura 1996). In addition, the balance between the $\mathrm{BC}$ poleward flow carrying warm and nutrient-poor water on the shelf edge and the cold and nutrient-rich water in subsurface layers is synergistically controlled by other mechanisms, including variations in the topographically induced flow around the cape (Rodrigues and Lorenzetti 2001); the instabilities of the Brazil Current, with its meanders sometimes invading the shelf area (Campos et al. 2000); and the enhanced vertical transport driven by wind stress curl over the midshelf (Castelao and Barth 2006, Castelao 2012). Thus, the region off the coast of Cabo Frio represents a special oceanographic gradient from the classical coastal Ekman upwelling to a typical oligotrophic western boundary current (Belem et al. 2013) and is considered a hot spot of productivity on the southeastern Brazilian shelf.

The oceanography of the Cabo Frio region is marked by the occurrence of the following three main water masses: the warm and low-salinity coastal water at the surface of the inner shelf $(\mathrm{CW}$ : $>15^{\circ} \mathrm{C}$; salinity, 32-34; $<50 \mathrm{~m}$ depth), resulting from the dilution of oceanic waters within the continental drainage area; the warm and salty tropical water at the surface in the outer shelf (TW: $24-28^{\circ} \mathrm{C}$; salinity, $\sim 37$; 0-200 $\mathrm{m}$ depth), which comprises the southward branch of the Brazil Current (BC); and the SouthAtlantic Central Water (SACW: $<18^{\circ} \mathrm{C}$; salinity, 3536.4), located almost constantly at the shelf bottom and periodically upwelled to the surface or subsurface 


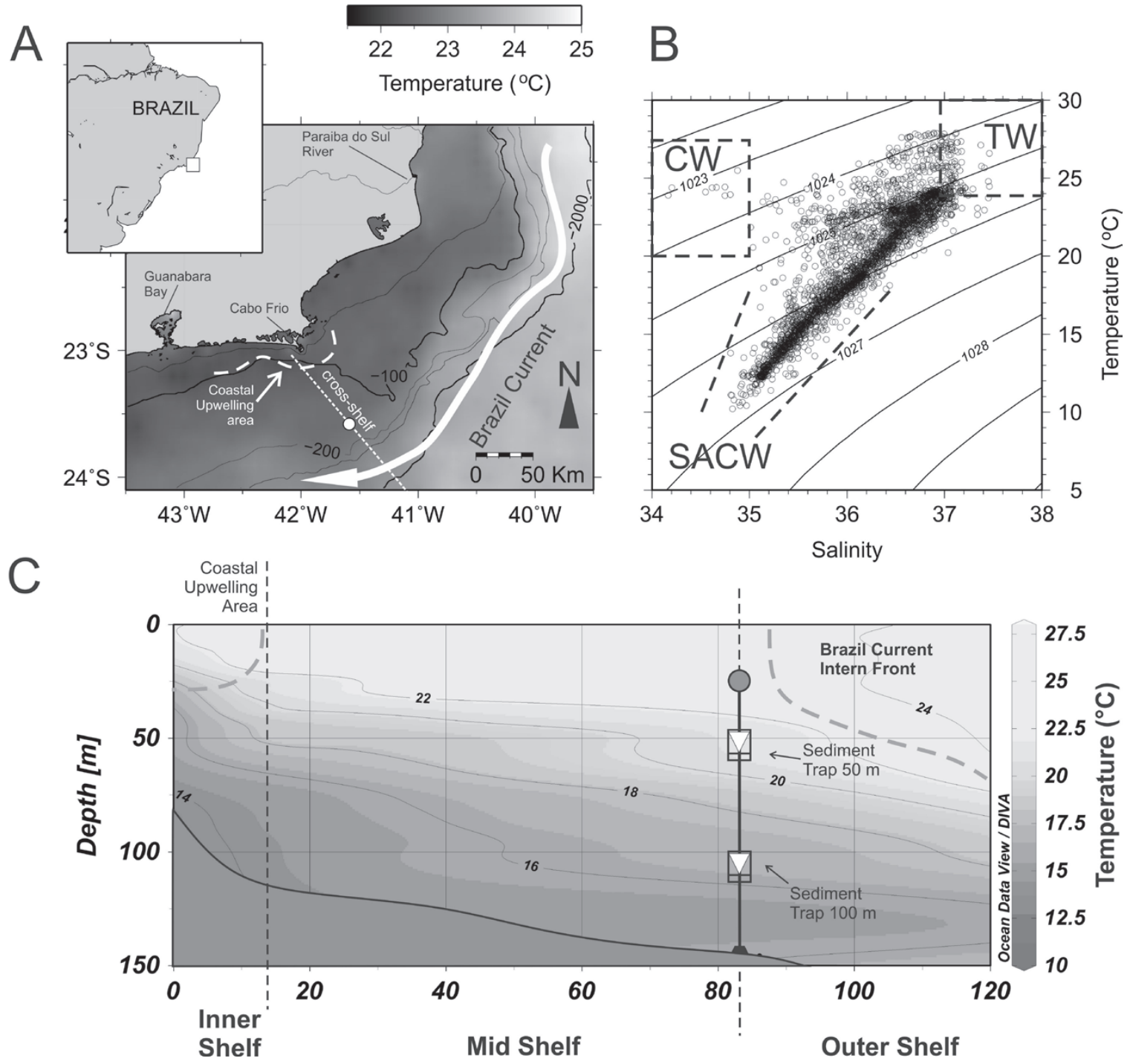

Figure 1 - (A) Study area offshore of Cabo Frio on the southeastern Brazilian Shelf. The mooring site is marked with a white circle. (B) T-S diagram from World Ocean Data Center, showing the distribution of T-S pairs in the upper layer on the region from 5 to $300 \mathrm{~m}$. See text for details. (C) Cross-shelf view of the Cabo Frio Upwelling System showing the thermal structure along the water column, the inner, mid- and outer shelf compartments and the position of the mooring site. Depth data are from ETOPO-2.

(Aidar et al. 1993, Franchito et al. 2008, Calado et al. 2010) (Figure 1B). The interaction among these three water masses, coupled with a complex pattern of flow that is also marked by the meandering of the $\mathrm{CB}$, is responsible for the sedimentation patterns on the Southeastern Brazilian Continental Margin (SEBCM) (Mahiques et al. 2004).

Moreover, the CFUS is formed by three interacting compartments, as observed through its cross-shelf section, producing effects on particle transport and settling (Figure 1C). These compartments can be described as follows: (1) The coastal upwelling area, represented by a narrow, nearshore area in the inner shelf, where the northeasterly prevailing winds favor the Ekman transport of surface waters (CW and TW) and result in a typical coastal upwelling mechanism that provides SACW to the surface close to the coast (Moreira da Silva 1973, 
Valentin and Kempf 1977, Valentin 1984, Franchito et al. 2008). Typically, the highly productive coastal upwelling plume is advected southwestward, following the coastline (Lorenzetti and Gaeta 1996);

(2) The mid-shelf area - this wide area covers the entire mid-shelf and is dominated by the effects of wind curl (Castelao and Barth 2006), thermal fronts (Castro et al. 2008) and small eddies induced by the meandering of the BC (Silveira et al. 2008, Calado et al. 2010). Although the upwelling of the SACW does not occur on the mid-shelf, it potentially intrudes into the photic zone, producing biogeochemical effects, such as enhancing primary production; (3) The outer shelf area, where the dominant mechanism is the mesoscale regional dynamics of the internal front of the $\mathrm{BC}$ and the breaking of internal waves and tidally induced vertical displacements (Pereira and Castro 2007). Despite the fact that the CFUS is one of the most studied environments of the Brazilian coast, the majority of the biological studies have been restricted to the inner shelf (Moreira da Silva 1973, Valentin and Kempf 1977, Valentin 1984, Knoppers and Moreira 1990, Gonzalez-Rodriguez et al. 1992, Franchito et al. 2008), and most of the oceanographic dynamics studies in the area address the mesoscale patterns (Castelao and Barth 2006, Silveira et al. 2008, Calado et al. 2010) without detailing the local mid-shelf dynamics or the SACW intrusion into the euphotic zone.

In addition to this oceanographic complexity, another important aspect of the CFUS, is the continental input represented by the presence of the Paraiba do Sul River (PSR) in the northwestern portion of the inner shelf(Figure 1). With an average suspended matter concentration of $35 \mathrm{mg} . \mathrm{L}^{-1}$ and sediment yield of 25-30 t. $\mathrm{km}^{-2} \cdot \mathrm{yr}^{-1}$ (Jennerjahn et al. 2010), the PSR contributes dissolved and particulate material to the $\mathrm{CW}$ in a well-established coastal plume. This riverine contribution is mainly controlled by the intensity and duration of the rainy season; the period of highest fresh water discharge is between December and April (Salomão et al. 2001).
Although the RPS discharge may be lower than other southeastern Brazilian rivers, Jennerjahn et al. (2010) suggest that the inputs in the dissolved phase are of major importance to the continental shelf, accounting for $80 \%$ of the total material load of the river. Occasionally, the dispersion of the Guanabara Bay plume can also reach the Cabo Frio shelf, contributing both dissolved ions and particulate matter. These contributions to the dissolved and particulate phases of continental material, associated with the coastal Ekman transport and eddy-induced activity in the mid-shelf, can lead to a complex mixture of signals from different sources and affects the composition of biogenic elements and the governing biogeochemical cycles as a whole.

\section{SEDIMENT TRAP MOORING DESIGN AND EXPERIMENTS}

We report here data from the CFUS Oceanographic Observatory (Mooring F-150) located at 233' S - 41 $34^{\prime} \mathrm{W}$ in a 145 -m-depth water column at the continental shelf edge in southeastern Brazil (Figure 1A). The F-150 mooring design is based on a $110 \mathrm{~m}$ vertical line with the topmost subsurface buoy positioned at $30 \mathrm{~m}$ depth, two sediment traps, temperature loggers and current meters deployed in four experiments between November 2010 and March 2012. The two conical sediment traps (hereafter referred to as STs), PARFLUX Mark 8-13 model (McLane Research Labs) with an aperture area of $0.66 \mathrm{~m}^{2}$, and $12500-\mathrm{mL}$ sequential bottles were installed along the mooring line at depths of $50 \mathrm{~m}$ and $100 \mathrm{~m}$. Upper and lower sediment trap sampling rates were configured synchronously, varying from five to seven days for different experiments, except for the first deployment from November through December 2010, during which the sampling interval was three days. Prior to deployment, each sample bottle was decontaminated and filled with pre-filtered MilliQ water with buffered $(\mathrm{pH}=8)$ formaldehyde (4\%) after adjusting the salinity with marine salt $\left(\right.$ RedSea $\left.^{\circ}\right)$ to 70 PSU to prevent the bacterial decomposition of the collected particles and loss 
of bottle water by diffusion (Goswami 2004). The time frame of these experiments varied between 38 and 98 consecutive days, covering the following periods: (I) from November 11 to December 19 of 2010 , covering the late spring and very beginning of summer of 2010; (II) from March 15 to June 14, covering the autumn of 2011; (III) from July 20 to September 26, covering the winter of 2011; and (IV) from December 2, 2011, to March 2, 2012, covering the late spring and summer. These experiments were labeled F-150\#01,\#02,\#03 and \#04, respectively, in the CFUS Oceanographic Observatory Database.

\section{GEOCHEMICAL ANALYSIS AND FLUXES}

To exclude zooplankton swimmers, after each mooring recovery, the sediment trap samples were wet-sieved through $1-\mathrm{mm}$ and $500-\mu \mathrm{m}$ meshes (Silverberg et al. 2006). One-quarter of each sample was filtered through pre-combusted $\left(450^{\circ} \mathrm{C} / 8 \mathrm{~h}\right)$ and pre-weighed Whatman GF/F membranes $(\varnothing$ $=47 \mathrm{~mm})$ (Grasshoff et al. 1999) and oven dried $\left(40^{\circ} \mathrm{C}\right)$ for 72 hours. Thereafter, the filters were used for the determination of total mass, and they were then exposed to $\mathrm{HCl}$ vapor to eliminate the carbonate fraction (Lorrain 2003) in order to analyze the particulate organic carbon (POC) and nitrogen $(\mathrm{PON})$ contents and the associated stable isotopes $\left(\delta^{13} \mathrm{C}\right.$ and $\left.\delta^{15} \mathrm{~N}\right)$. Bulk analyses (POC, PON, $\delta^{13} \mathrm{C}$ and $\left.\delta^{15} \mathrm{~N}\right)$ were performed with an elemental analyzer (Europa ANCA-GSL) coupled to a mass spectrometer (PDZ Europa 20-20) at the Isotope Facility Laboratory, University of California, Davis, USA.

Isotopic ratios $(\mathrm{R})$ are reported relative to the international standards of Vienna Pee Dee belemnite (V-PDB) for carbon and atmospheric $\mathrm{N}_{2}$ for nitrogen following the standard delta notation:

$\delta(\%)=\left[\left(\mathrm{R}_{\text {sample }} / \mathrm{R}_{\text {standard }}\right)-1\right] * 1000$

Total mass fluxes (TMF) and particulate organic carbon fluxes $\left(\mathrm{POC}_{\text {flux }}\right)$ were calculated as follows:
Flux $=\left(\mathrm{SF}^{*} \alpha\right) /\left(\mathrm{A}^{*} \gamma\right)$

where SF represents the sample split factor, which was 4 in this study; $\alpha$ represents the total mass of the sample for TMF or the mass of organic carbon for POC flux calculations; $\mathrm{A}$ is the area of the sediment trap funnel opening $\left(0.66 \mathrm{~m}^{2}\right)$; and $\gamma$ represents the time (interval) of exposure or integration per sample (Silverberg and Bahena 2007, Aguiñga et al. 2010). All pre- and posthandling of samples were performed using protocols registered at LOOP-UFF (Laboratory of Operational Oceanography and Paleoceanography - Fluminense Federal University).

\section{Physical Data ACQUisition}

Oceanographic data used to compare against the sediment trap data were collected by a series of 22 ONSET TidbiT V2 temperature loggers spaced at approximately $5 \mathrm{~m}$ intervals between 120 and $30 \mathrm{~m}$ and by two $400-\mathrm{KHz}$ Nortek Aquadopp Profilers installed at midwater (upward- and downward-looking) that sampled the entire water column at a $3 \mathrm{~m}$ cell spacing. The sampling rate of each temperature logger and current meter was adjusted to 30 min. The eastern component of the flow was decomposed into cross-shelf direction (dotted line in Figure 1A) defined with respect to the average direction of the $200 \mathrm{~m}$ isobath northeast of the mooring site. Surface wind speeds during the observation period were obtained from the NCEP Reanalysis-2 and plotted at six-hour intervals. To provide complementary data, the euphotic zone depth $\left(Z_{\text {eu }}\right)$ was estimated using MODIS Chlorophyll-a eight-day composites (http://oceancolor.gsfc.nasa.gov) and the algorithm proposed by Morel et al. (2007) and Shang et al. (2011). The band in Figure 2C was drawn assuming a 35\% error in the surface chlorophyll estimates from the OC $3 \mathrm{M}$ band ratio algorithm (O'Reilly et al. 2000). 


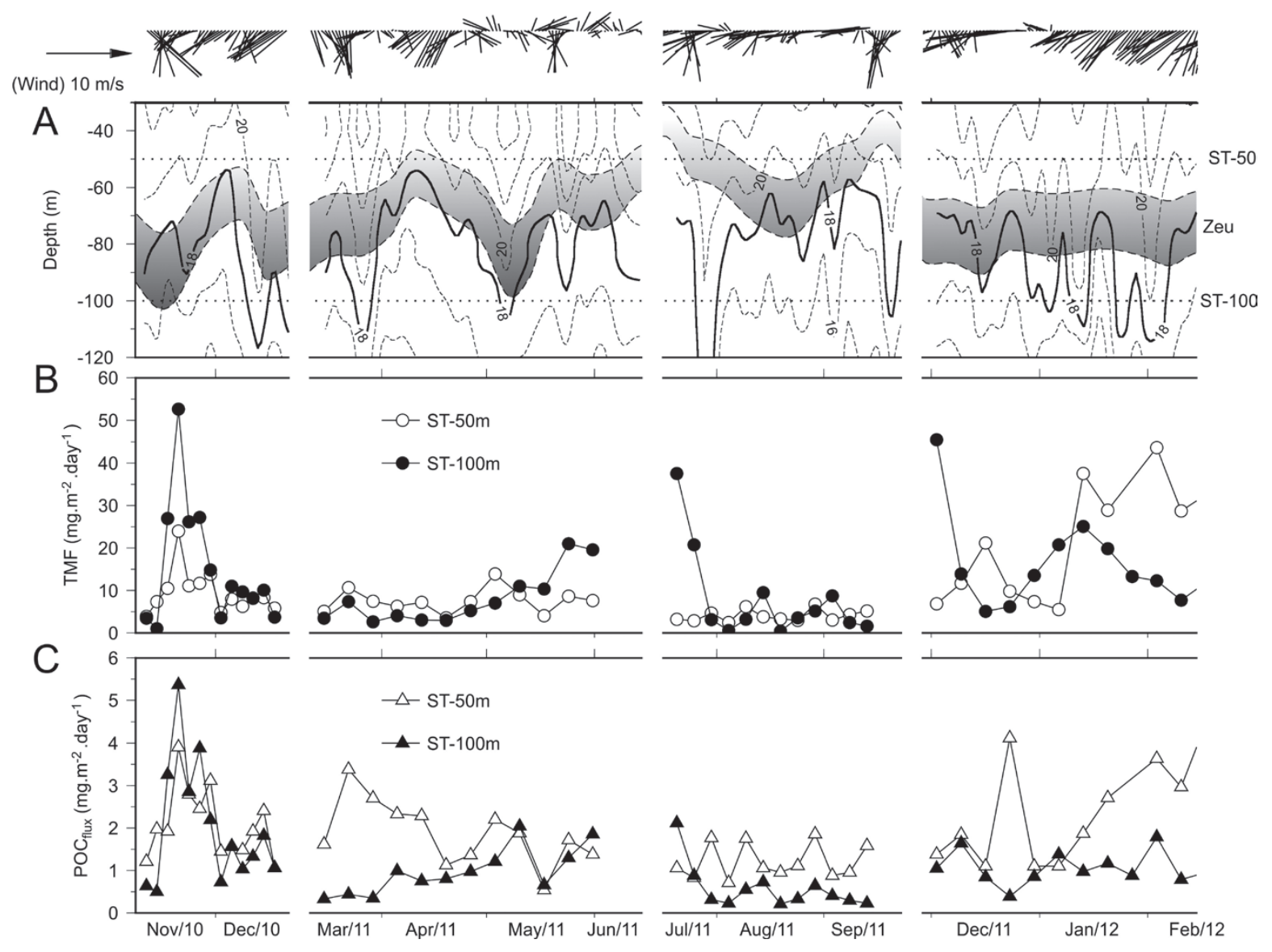

Figure 2 - (A) Regional winds vectors obtained from ASCAT Program, temporal variability of the water column thermal structure. The $18^{\circ} \mathrm{C}$ isotherm depth represents the upper temperature limit of South Atlantic Central Water. The grey area represents the photic zone depth (Zeu) estimated from MODIS/AQUA Chrorophyll 8-day data. (B) Total mass fluxes (TMF), expressed as mg.m ${ }^{2}$.day ${ }^{-1}$ and $(\mathbf{C})$ Particulate Organic Carbon fluxes $\left(\mathrm{POC}_{\text {flux }}\right.$ ), expressed as $\mathrm{mgCOT} . \mathrm{m}^{-2}$.day ${ }^{-1}$, captured in sediment traps between November 2010 and February 2012. The open circles and triangles represent the $50 \mathrm{~m}$ sediment trap (ST-50 m), and the closed circles and triangles represent the $100 \mathrm{~m}$ sediment trap (ST-100 m).

\section{RESULTS}

Spearman rank correlation coefficients were calculated for the physical and geochemical parameters measured in the mooring to determine relationships among variables. The Spearman correlation coefficient (r) was calculated for a confidence level of $95 \%(p<0.05)$. For the physical parameters, the euphotic layer $\left(Z_{\text {eu }}\right)$ was considered the mean depth of the euphotic band (Figure 2A) and is expressed as its negative depth related to zero at the surface; the $18^{\circ} \mathrm{C}$ isotherm depth represents the upper limit of SACW and is also expressed as its negative depth related to the surface.

\section{PhySiCAL PARAMETERS}

Offshore winds during the experiments were predominantly from the northeast, occasionally interrupted by the advance of atmospheric cold front passages when the wind direction rotated to the southern quadrant, especially during the autumn-winter months (April to September) (Figure 2). A depthdependent time series of the water temperature revealed the quasi-permanent presence of SACW $\left(\mathrm{T} \leq 18^{\circ} \mathrm{C}\right)$ at the bottom layers of the water column. A high-frequency vertical displacement of the $18^{\circ} \mathrm{C}$ isotherm was observed throughout the 
sampling period; however, both the frequency and the intensity of the isotherm downwelling seemed to have been higher in the summer of 2012, and the scale of vertical displacement was consistent with observations by Pereira and Castro (2007). Most of the time, the SACW was at the depth of the euphotic zone; nevertheless, during the spring and summer, a vertical incursion of the $18^{\circ} \mathrm{C}$ isotherm into the euphotic zone became more frequent (Figure 2A). Observed temperatures higher than $18^{\circ} \mathrm{C}$ may have been representative of tropical water (TW) and/ or coastal water $(\mathrm{CW})$ or perhaps a mix of both. Isolated occurrences of warmer temperatures ( $T$ $\geq 24^{\circ} \mathrm{C}$ ) were observed during autumn (March to June), and these temperatures likely represented the dominance of the internal front of the $\mathrm{BC}$ in the area (Belem et al. 2013).

Magnitude AND TEMPoral VARIABILITy of PARTICULATE

FLUXES IN THE SEDIMENT TRAPS

A total of 98 samples were collected and analyzed, and the range and statistical parameters (average and standard deviation) of total mass fluxes (TMF) and particulate organic fluxes $\left(\mathrm{POC}_{\text {flux }}\right)$ for both sediment traps are summarized in Table I. There were some inconsistencies in the timing and magnitude of the fluxes between the two traps (upper and lower STs), suggesting that lateral transport may be relevant in some occasions, especially in deeper layers (below $\sim 50 \mathrm{~m}$ depth). However, the recorded total mass and organic carbon fluxes are positively well correlated in the upper $(\mathrm{r}=0.78)$ and lower $(\mathrm{r}=0.80)$ traps (Table II). The range of the total mass and organic carbon fluxes are highly variable throughout the year, with larger fluxes occurring during the summer season, whereas lower fluxes were observed during the winter (Figure 2B, C).

The total mass fluxes (TMF) in the upper ST ranged from $2.48 \mathrm{mg} \cdot \mathrm{m}^{-2}$. day ${ }^{-1}$ in August 2011 to $43.61 \mathrm{mg} \cdot \mathrm{m}^{-2}$.day ${ }^{-1}$ in February 2012, whereas in the lower trap, they varied between $0.41 \mathrm{mg} . \mathrm{m}^{-}$ ${ }^{2}$.day ${ }^{-1}$ in August 2011 to $52.70 \mathrm{mg} \cdot \mathrm{m}^{-2}$. day ${ }^{-1}$ in November 2010 (Figure 2B). The particulate organic carbon fluxes $\left(\mathrm{POC}_{\text {flux }}\right)$ in the upper trap varied between a minimum of $0.54 \mathrm{mg} \cdot \mathrm{m}^{-2} \cdot \mathrm{day}^{-1}$ in May 2011 and a maximum of $4.43 \mathrm{mg} \cdot \mathrm{m}^{-2}$. day ${ }^{-1}$ in December 2011. For the lower sediment trap, the $\mathrm{POC}_{\text {flux }}$ ranged from $0.21 \mathrm{mg} \cdot \mathrm{m}^{-2}$. day ${ }^{-1}$ in August 2011 to $5.37 \mathrm{mg} \cdot \mathrm{m}^{-2}$. day $^{-1}$ in November 2010 (Figure 2C). The organic carbon content ranged from 6.5 to $29 \%$ of the trapped total mass.

\section{BULK GEOCHEMISTRY PROPERTIES OF TRAPPED PARTICLES}

The bulk geochemical properties of the particulate organic matter collected by the sediment traps

TABLE I

Minimum, maximum and average values to Total Mass Fluxes (TMF) and Particulate Organic Fluxes $\left(\mathrm{POC}_{\text {flux }}\right)$ obtained along the four mooring experiments for the upper (UST) and the lower (LST) sediment traps deployed in Cabo Frio shelf.

\begin{tabular}{|c|c|c|c|c|c|}
\hline \multirow{2}{*}{ Mooring Experiment (ME) } & & \multicolumn{2}{|c|}{ TMF $\left(\mathrm{mg} \cdot \mathrm{m}^{-2} \cdot\right.$ day $\left.^{-2}\right)$} & \multicolumn{2}{|c|}{ POC $_{(\text {flux) }}\left(\mathrm{mg} \mathrm{m}^{-2} \cdot \mathrm{day}^{-2}\right)$} \\
\hline & & Range (Min.-Max) & Avrge \pm Std. Dev. & Range (Min.-Max) & Avrge \pm Std. Dev. \\
\hline \multirow{2}{*}{$\begin{array}{c}\text { ME - I } \\
\text { (Late Spring 2010) }\end{array}$} & UST & $3.89-23.90$ & $9.50 \pm 5.18$ & $1.10-3.90$ & $2.09 \pm 0.81$ \\
\hline & LST & $1.06-52.70$ & $15.27 \pm 14.54$ & $0.50-5.40$ & $2.01 \pm 1.45$ \\
\hline \multirow{2}{*}{$\begin{array}{c}\text { ME - II } \\
\text { (Autumn 2011) }\end{array}$} & UST & $3.54-13.90$ & $7.56 \pm 2.84$ & $0.54-3.40$ & $1.87 \pm 0.76$ \\
\hline & LST & $2.62-20.90$ & $8.14 \pm 6.33$ & $0.33-2.00$ & $0.97 \pm 0.55$ \\
\hline \multirow{2}{*}{$\begin{array}{c}\text { ME - III } \\
\text { (Winter 2011) }\end{array}$} & UST & $2.48-6.75$ & $4.06 \pm 1.38$ & $0.71-1.85$ & $1.21 \pm 0.41$ \\
\hline & LST & $0.41-37.49$ & $8.05 \pm 10.84$ & $0.21-2.11$ & $0.58 \pm 0.53$ \\
\hline $\mathrm{ME}-\mathrm{IV}$ & UST & $5.48-43.61$ & $21.23 \pm 13.69$ & $1.09-4.43$ & $2.39 \pm 1.25$ \\
\hline (Spring 2011 - Summer 2012) & LST & $5.05-45.44$ & $16.22 \pm 10.95$ & $0.38-1.78$ & $1.05 \pm 0.39$ \\
\hline
\end{tabular}

Note: UST=Upper Sediment Trap (50 m); LST=Lower Sediment Trap (100 m) 
TABLE II

Spearman rank correlation coefficients on measured parameters for a 95 confidence level ${ }^{\mathrm{a}}$.

\begin{tabular}{|c|c|c|c|c|c|c|c|c|}
\hline & ${ }^{\mathrm{b}} \mathbf{Z}_{\mathrm{eu}}$ & $\begin{array}{c}18^{\circ} \mathrm{C} \\
\text { isotherm } \\
\text { depth }\end{array}$ & TMF & POC $_{\text {flux }}$ & $\%$ POC & $\%$ PON & $\mathbf{C} / \mathbf{N}$ & $\delta^{13} \mathrm{C}$ \\
\hline \multicolumn{9}{|l|}{ UPPER ST (50m) } \\
\hline $18^{\circ} \mathrm{C}$ isotherm depth & 0.513 & & & & & & & \\
\hline TMF & -0.579 & -0.297 & & & & & & \\
\hline $\mathrm{POC}_{\text {flux }}$ & -0.421 & -0.295 & 0.785 & & & & & \\
\hline$\%$ POC & 0.419 & 0.205 & -0.621 & -0.085 & & & & \\
\hline$\% \mathrm{PON}$ & 0.529 & 0.268 & -0.725 & -0.331 & -0.819 & & & \\
\hline $\mathrm{C} / \mathrm{N}$ & -0.203 & 0.010 & 0.229 & -0.085 & 0.026 & -0.473 & & \\
\hline$\delta^{13} \mathrm{C}$ & 0.024 & -0.048 & 0.031 & 0.185 & 0.204 & 0.195 & 0.033 & \\
\hline$\delta^{15} \mathrm{~N}$ & 0.135 & 0.407 & -0.257 & 0.057 & 0.513 & 0.232 & 0.558 & 0.134 \\
\hline \multicolumn{9}{|l|}{ LOWER ST (100m) } \\
\hline $18^{\circ} \mathrm{C}$ isotherm depth & 0.513 & & & & & & & \\
\hline TMF & -0.267 & -0.182 & & & & & & \\
\hline $\mathrm{POC}_{\text {flux }}$ & -0.401 & -0.145 & 0.804 & & & & & \\
\hline$\%$ POC & -0.132 & 0.180 & -0.602 & -0.068 & & & & \\
\hline$\% \mathrm{PON}$ & 0.144 & 0.348 & -0.680 & -0.286 & 0.820 & & & \\
\hline $\mathrm{C} / \mathrm{N}$ & -0.285 & -0.268 & 0.347 & 0.338 & -0.191 & -0.662 & & \\
\hline$\delta^{13} \mathrm{C}$ & -0.245 & -0.027 & 0.443 & 0.677 & 0.101 & -0.170 & 0.411 & \\
\hline$\delta^{15} \mathrm{~N}$ & 0.012 & 0.121 & 0.112 & 0.386 & 0.294 & 0.113 & 0.245 & 0.559 \\
\hline
\end{tabular}

${ }^{\mathrm{a}}$ Numbers in bold/italic represent significant correlations at $\mathrm{p}<0.05 .{ }^{\mathrm{b}} \mathrm{Z}_{\text {eu }}$ position is presented by its mean depth.

showed a wide range of values (Figure 3). Both the maximum and minimum POC content were recorded in the lower ST, which oscillated from $23.1 \mathrm{mg} \cdot \mathrm{g}^{-1}$ in December 2011 to $491.1 \mathrm{mg} \cdot \mathrm{g}^{-1}$ in August 2011, whereas in the upper trap, a narrower range was recorded, varying between $49.9 \mathrm{mg} \cdot \mathrm{g}^{-1}$ and 417.4 mg.g ${ }^{-1}$, both in December 2011. The C/N ratios varied between 2.2 and 6.4 in the upper ST and from 2.1 to 11.9 in the lower ST, with no clear pattern associated with the seasons. The organic carbon and nitrogen stable isotope compositions also exhibited a wide range, which may represent different mixtures from multiple sources. Organic $\delta^{13} \mathrm{C}$ values ranged between -21.6 and $-25.6 \%$ in the upper ST and between -21.4 and $-27.3 \%$ in the lower ST, which recorded most of the lighter values. Similar to stable carbon, $\delta^{15} \mathrm{~N}$ also exhibited a large variance, from 6.6 to $-4.0 \%$ and from 5.9 to $-4.7 \%$ in the upper and lower STs, respectively (Figure 3).
Physical and Geochemical Statistical Coupling

Spearman's rank correlation analysis between the physical and geochemical data showed that the upper and lower STs exhibited different geochemical responses to physical forcing (Table II). It is important to emphasize that, although the correlations between some physical and geochemical data were statistically significant $(p<0.05)$, they were relatively weak. This finding can basically be explained by differences in the sampling frequency between physical and geochemical data but also by the synergistic effect of multiple physical forcing factors. Similar results were found by Belem et al. (2013) working only with physical variables. Under these conditions, statistical significance was useful as a tool to highlight potential causality between physical forcing and geochemical parameters.

In the upper ST, both total mass and particulate organic carbon fluxes were negatively correlated 

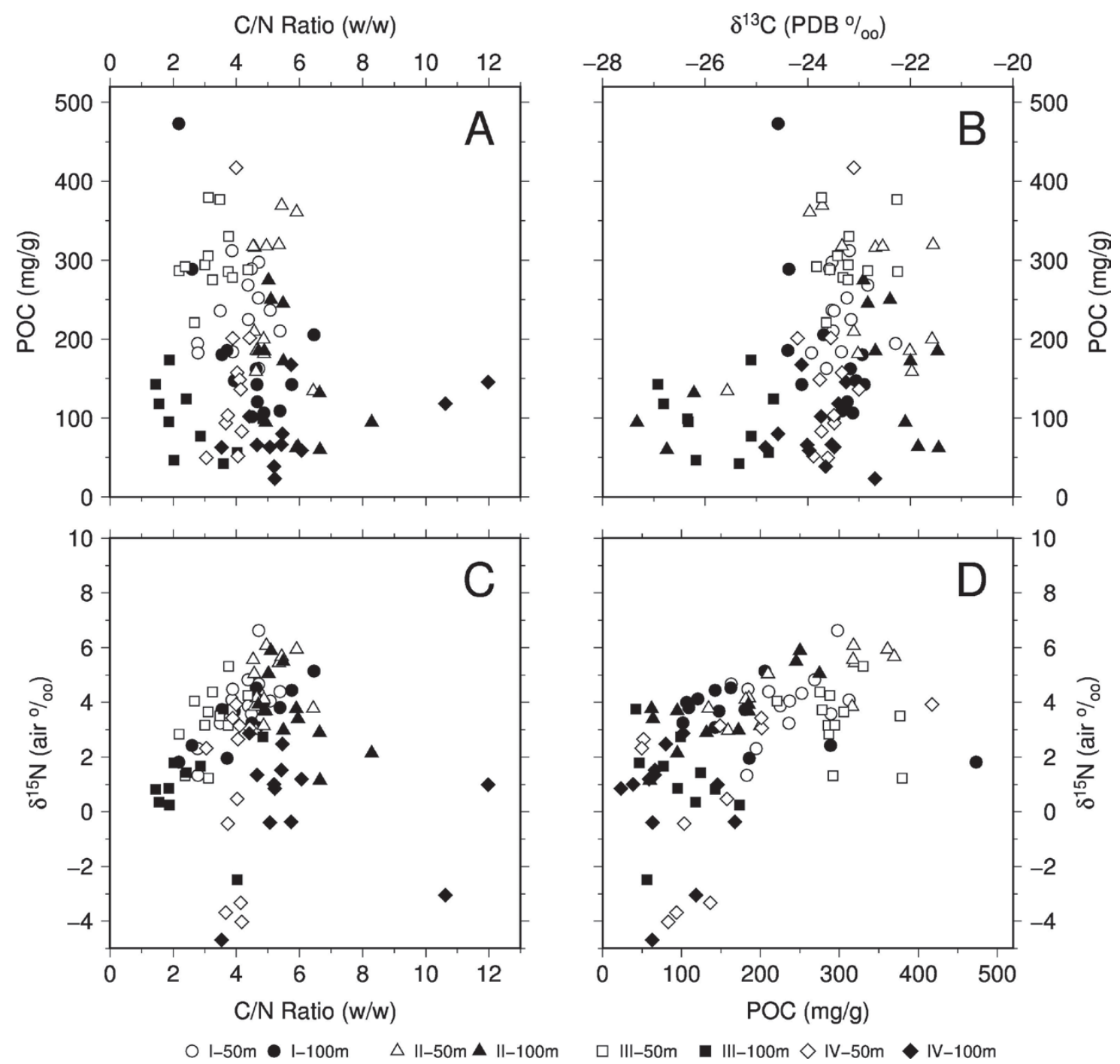

Figure 3 - Bulk geochemical scatterplot graphics for particles trapped on the Cabo Frio Upwelling System during the four mooring deployments. (A) Scatterplot graphic between particulate organic carbon (POC) and C/N ratio; (B) stable carbon isotopic composition $\left(\delta^{13} \mathrm{C}\right)$; (C) scatterplot graphic between stable nitrogen composition $\left(\delta^{15} \mathrm{~N}\right)$ and $\mathrm{C} / \mathrm{N}$ ratio; and (D) particulate organic carbon content. Open and closed circles, triangles, squares and diamonds represent the $50 \mathrm{~m}$ and $100 \mathrm{~m}$ depth mooring deployment I (November to December 2010), II (March to June 2011), III (July to September 2011) and IV (December 2011 to February 2012), respectively.

with euphotic layer depth ( $\mathrm{r}=-0.58$ for TMF and $\mathrm{r}=-0.42$ for $\mathrm{POC}_{\text {flux }}$ ), indicating that light penetration is relevant to the upper trap fluxes and suggesting that local primary productivity may be important to the fluxes in the upper layer. Furthermore, TMFs and $\mathrm{POC}$ fluxes were also correlated with the depth of the $18^{\circ} \mathrm{C}$ isotherm ( $\mathrm{r}=-0.30$ for both correlations). Although it is a weak correlation, its significance confirms the importance of the nutrients reaching the euphotic zone to the mass and organic carbon fluxes. Most of the bulk geochemistry data (i.e., POC content, $\mathrm{C} / \mathrm{N}$ ratios and stable carbon isotopes) in the upper trap showed no significant correlation with physical parameters. However, the $\delta^{15} \mathrm{~N}$ signal is an exception because it shows a significant and positive correlation with the depth of the $18^{\circ} \mathrm{C}$ 
isotherm $(r=0.41)$, indicating that the degree of isotopic fractionation recorded in the particulate trapped material may depend on the availability of nutrients. Among the geochemistry parameters, TMF showed a negative correlation with POC content $(\mathrm{r}=-0.62)$, indicating that the higher the mass fluxes, the lower the organic content, which marks the effect of dilution by lithogenic and/or carbonatic material. In addition, the $\delta^{15} \mathrm{~N}$ signal was positively correlated with both POC content $(\mathrm{r}=0.51)$ and $\mathrm{C} / \mathrm{N}$ ratios $(\mathrm{r}=0.56)$.

In the lower ST, TMF data showed no correlation with any of the physical parameters, whereas it showed a significant correlation with most of the bulk geochemical parameters, indicating that oceanography conditions has less control over the TMF and providing a strong signal of its source. In addition, the POC fluxes exhibited a significant correlation with euphotic layer depth $(\mathrm{r}=-0.40)$, demonstrating that the vertical transport of local productivity could not be ignored. However, in contrast to the upper ST observations, a correlation between POC fluxes and $18^{\circ} \mathrm{C}$ isotherm depth was not recorded. POC fluxes were also positively correlated with $\mathrm{C} / \mathrm{N}$ ratios $(\mathrm{r}=0.34)$ and $\delta^{13} \mathrm{C}$ $(\mathrm{r}=0.68)$ and $\delta^{15} \mathrm{~N}$ signals $(\mathrm{r}=0.39)$, reaffirming that there is a strong relationship between lower ST fluxes and their sources. Among the bulk geochemical parameters, organic $\delta^{13} \mathrm{C}$ values were correlated with TMF ( $\mathrm{r}=0.44)$, POC fluxes $(\mathrm{r}=0.68)$ and $\delta^{15} \mathrm{~N}$ values $(\mathrm{r}=0.56)$, suggesting that higher fluxes carry lighter carbon isotopes and that they partially come from land-delivered material, which is also consistent with their lower $\delta^{15} \mathrm{~N}$ values.

\section{DISCUSSION}

Physical PARAMETERS AND TEMPORAL VARIABILITY OF PARTICLE FLUXES

The variability of the thermal structure on the Cabo Frio shelf edge is not dominated by a single factor. Instead, it is related to the action of multiple factors, such as the influence of the BC front, cross-isobath transport and wind-stress-curl-driven upwelling (Belem et al. 2013). Therefore, a number of different mechanisms combine to control the magnitude and timing of particulate sources and fluxes on the shelf edge. These mechanisms may include incursions of the internal front of the $\mathrm{BC}$ on the shelf (and it's associated meanders and eddies on the shelf edge), the availability of SACW on the bottom layers and the dispersion of coastal plumes. The primary production induced by the intrusion of nutrient-rich SACW in the euphotic layer is also enhanced by the local action of the wind stress curl. The combination of all these physical factors plus the associated biological effects might have produced the diverse geochemical events that were recorded in the upper and lower ST.

The mid-shelf wind pattern confirmed the expected seasonality. The predominant northeast winds exhibited frequent reversals in their direction during the winter due to the passage of frontal systems propagating northward. According to Castro et al. (1987), southern-quadrant winds are associated with SACW downwelling and its retreat toward the shelf edge. Nevertheless, our mooring data do not show a clear direct correlation between mid-shelf winds and SACW (or $18^{\circ} \mathrm{C}$ isotherm) depth, confirming the findings of Belem et al. (2013), who showed that the thermal structure of the water column on the Cabo Frio shelf edge responds to multiple interacting factors and not only to the wind stress. Based on these observations, we can assume that processes related to the timing and magnitude of particulate fluxes on the mooring site are not exactly the same as those operating on the coastal upwelling area, where the dynamics are regulated almost completely by the wind stress (Lorenzetti and Gaeta 1996).

The thermal structure of the water column on the Cabo Frio shelf edge was quite variable, exhibiting high oscillations at hourly or daily tidally induced frequencies (Figure 2A). Although it seems 
that there is a seasonal signal in the hydrodynamics affecting the variability in the depth of the $18^{\circ} \mathrm{C}$ isotherm, a clear pattern was not detected. The depth of the $18^{\circ} \mathrm{C}$ isotherm, which marks the upper limit of the SACW, oscillated between 60 and $110 \mathrm{~m}$, with an average depth of approximately $70 \mathrm{~m}$ during all experiments, and intruded into the euphotic zone multiple times, identified here as SACW intrusions that act as injections of nutrients in the surface layer. Sub-surface temperatures changed throughout the year, with higher temperatures up to $24^{\circ} \mathrm{C}$ during the autumn, suggesting that the $\mathrm{BC}$ internal front oscillated closer to the shelf.

Examining the variability of the total mass and organic carbon fluxes with respect to the water column thermal structure and light penetration provided insights into the mechanisms that cause such variations (Figure 2B,C). The significant correlation obtained among the total mass and organic carbon fluxes and physical parameters (euphotic layer and $18^{\circ} \mathrm{C}$ isotherm depth) in the upper trap indicates that the local physical condition is determinant on the fluxes recorded. In contrast, in deep layers, physical parameters seem to be less important, as shown by the fluxes in the lower ST. Only POC fluxes showed a significant correlation with the euphotic layer above, suggesting that even the local physical conditions are not primarily relevant, but at least some of organic carbon fluxes are provided through the settling of particles from the upper layer (Table II). The lack of coherence between the magnitude of the fluxes recorded in the upper and lower STs contributed even more complexity. At the same time, this result also provides some understanding of the particle sources in both traps. In this sense, whereas the upper sediment trap fluxes appear to be related to local productivity variability, the lower ST seems to exhibit a combination of particles resulting from vertical settling in addition to long-distance laterally transported material.
Despite the fact that there is no obvious seasonal pattern for all fluxes, based on the timing and magnitude of the main peaks, two main types of physical-geochemical coupling scenarios were recognized: (1) Condition \#1: TMF and POC fluxes are coincident with the intrusion of the $18^{\circ} \mathrm{C}$ isotherm (SACW) in the euphotic zone, even assuming some delays. This condition occurred mostly during springsummer, e.g., November 2010 and May and December 2011. (2) Condition \#2: complete decoupling among fluxes and the depth of the $18^{\circ} \mathrm{C}$ isotherm (i.e., the presence of SACW in shallow layers). In these cases, regardless of the variation of the depth of the $18^{\circ} \mathrm{C}$ isotherm, the fluxes did not change much. Condition \#2 is mainly representative of autumn-winter flux variability and can also be associated with the more intense presence of the internal front of the $\mathrm{BC}$ (Belem et al. 2013). The absence of data on nutrient levels and biological structure on the shelf edge area affects our understanding of the variability of these fluxes. However, because the higher mass and organic carbon fluxes are coincident with the rainy season, when river runoff is enhanced, we hypothesize that, in addition to the nutrient availability due to the almost constant presence of SACW in the euphotic layer, there is also a fertilizing effect provided by riverine plumes spreading on the shelf. Furthermore, lithogenic riverine particles may also contribute as settling ballast, as demonstrated in the works of Thunell (1998) and Armstrong et al. (2001).

Overlapping the two main physical-geochemical coupling scenarios, singular downwelling events can enhance the particle fluxes, as observed in the experiment of May 2011. This unusual event may be related to the $\mathrm{BC}$ oscillation and small eddy-induced circulation on the shelf, which can influence particle settling. Although our data are restricted to a single location at the shelf edge, which prevents the accurate identification of eddy activity, previous studies have shown the role of $\mathrm{BC}$ eddies and meanders on the Cabo Frio shelf (Calado et al. 2008). O'Brien et al. (2013), 
studying particles fluxes in the Arctic Ocean, also observed an increase in mass fluxes in the sediment traps due to a downward eddy effect. In contrast, a few events of warm-water downwelling occurred during the experiments, e.g., in July 2011, without similar particle-settling responses, which complicates the definition of a singular mechanism of sedimentation.

Bulk Geochemical Properties as a Proxy for Multiple SOURCES

The bulk organic matter data on the Cabo Frio continental shelf also exhibited a wide range of values, indicating multiple sources of particulate material. Two major sources appear to dominate fluxes in different degrees of mixture: marine phytoplankton-derived material from surface waters and long-distance transported land-derived material. The total mass fluxes in the upper ST were significantly correlated with OC content, showing that higher fluxes present a high content of organic carbon. This finding suggests a clear marine contribution to the particulate material. However, the fluxes of neither total mass nor POC were correlated with the bulk geochemical parameters, suggesting a high variability in the sources of particles caught in the upper sediment trap. In contrast, the fluxes of both TMFs and POC in the lower ST were significantly correlated with most of the bulk geochemical proxies. Total mass fluxes exhibited a negative correlation with OC content, showing an inverse pattern compared to that recorded in the upper ST. Therefore, we can conclude that the higher the total mass fluxes, the lower the OC content. In this case, the results suggest an influence of lithogenic material in the lower trap, which points to a relevant landderived material that is laterally transported. This observation is corroborated by the positive correlation found between the $\mathrm{C} / \mathrm{N}$ ratio and $\delta^{13} \mathrm{C}$ data with total mass fluxes. Finally, POC fluxes in the lower ST were also positively correlated with the $\mathrm{C} / \mathrm{N}$ ratio, $\delta^{13} \mathrm{C}$ and $\delta^{15} \mathrm{~N}$ data, which confirms the relevance of long-distance-transported landderived particles in the lower sediment trap (Table II).

In contrast to what was observed for the fluxes, the organic carbon (OC) content did not show any seasonal variability (Figure 3). The mostly organic carbon-enriched material was caught in the upper ST, which is consistent with a record of local productivity, whereas the organic carbonpoor material caught in the lower trap confirms its primarily long-distance origin. Despite this evidence, the $\mathrm{C} / \mathrm{N}$ ratio is mostly representative of fresh marine sources for both traps. Extremely low $\mathrm{C} / \mathrm{N}$ values of approximately 2 were recorded during the winter, mainly in the lower ST, suggesting bacteria-derived organic matter (Meyers and Teranes 2001, Ogrinc et al. 2005, Sampaio et al. 2010). However, the organic carbon content of these low-C/N ratio samples varied widely, ranging from less than $50 \mathrm{mg} \cdot \mathrm{g}^{-1}$ to the higher OC content of $500 \mathrm{mg} \cdot \mathrm{g}^{-1}$, indicating different degrees of bacterial colonization, which provide clues about the distance that the material was transported. Higher $\mathrm{C} / \mathrm{N}$ values, approximately 10-12, were recorded in the lower ST during summertime and showed relatively low $\mathrm{OC}$ content, indicating more refractory organic matter (Figure 3A). The $\delta^{13} \mathrm{C}$ signal of the organic carbon-poor material caught in the lower sediment trap showed the largest recorded range, varying between -27.3 and $-21.4 \%$, confirming its origin from multiple sources (Jasper and Gagosian 1990, Tesi et al. 2007). Particles from autumn and winter experiments (Moorings II and III) registered a lighter $\delta^{13} \mathrm{C}$ signal, typically indicating a high contribution of land-derived material. Data from the signal-to-noise ratio obtained from the current meters and corrected for the distance from the equipment at the mooring site (not shown here) indicate that resuspension is not significant or is even absent. However, the current strength remains high down to just $10 \mathrm{~m}$ above the sea floor; thus, 
long-distance transport is still supported. In contrast to the lower ST, the upper trap exhibited a narrower range of $\delta^{13} \mathrm{C}$ values (-21.6 to $-25.6 \%$ ), suggesting a predominance of marine organic matter and a lower degree of marine-land mixture (Figure 3B).

Assuming that the typical $\delta^{15} \mathrm{~N}$ of marine nitrate ranges between 5 and 6\%o (Liu and Kaplan 1989, Sigman et al. 2000, Robinson et al. 2012) and that particulate $\delta^{15} \mathrm{~N}$ variations mainly reflect isotopic fractionation due to $\mathrm{N}$-nutrient uptake in the euphotic layer but also some degree of organic matter source changes (Alt-Epping et al. 2007), the low mean values recorded for the particulate $\delta^{15} \mathrm{~N}$ (2-3\%o) in Cabo Frio may reflect the influence of the western boundary oligotrophic current on the shelf edge. High $\delta^{15} \mathrm{~N}$ values, approximately $6 \%$, were recorded during autumn-winter in the upper sediment trap, suggesting that N-nutrient uptake was not high enough to produce a shift in the nitrate isotopic range (Robinson et al. 2012). In contrast, almost all spring-summer data present low values of $\delta^{15} \mathrm{~N}$, indicating an isotopic fractionation due to intensive N-uptake (Figure 3D). These low $\delta^{15} \mathrm{~N}$ values may also indicate the occurrence of nitrogen fixation by diazotrophic cyanobacteria due to an extreme nitrogen deficiency (Hastings et al. 2003, Alt-Epping et al. 2007, Knapp et al. 2010). Moreover, very low or negative $\delta^{15} \mathrm{~N}$ values may also represent different degrees of mixture with land-derived material (Alt-Epping et al. 2007) (Figure 3C, D).

Considering that most particulate material caught in sediment traps represents a mixture of sources, as shown by bulk geochemical properties, we used the carbon and nitrogen stable isotope ranges of both sediment trap samples and potential sources to evaluate what the main sources were as well as the degree of mixture. The stable isotopic ranges of the Paraiba do Sul River (Kahler and Voss 1996), Guanabara Bay (Carreira et al. 2002) and Cabo Frio sediments (Mahiques et al. 2005) and sediment traps (this study) are plotted in Figure 4.
These results confirm the intense degree of mixed sources, in which the continental influence is well marked. Despite this mixing, the particulate matter caught in the sediment traps does not fully represent any of the potential sources considered in Figure 4. Even though the carbon isotopic range indicates the potential contribution of the Paraiba do Sul River, and a less significant contribution from Guanabara Bay, the stable nitrogen signal in the sediment traps is considerably lighter than potential sources. Local phytoplankton production in a nitrate-limited environment mixed in varied degrees with diagenetic transformed material seems to be the main source of the particles caught in the shelf edge traps. Moreover, the predominance of vascular plant sources was also recorded in the lower ST, confirming the importance of the longdistance transport of refractory material to the shelf edge, especially during the autumn and winter.

\section{CONCLUSIONS}

Although the Cabo Frio Upwelling System is one of the best studied coastal areas on the Brazilian coast, most biological-geochemical research have focused on the near-shore coastal upwelling zone, whereas physical studies have mainly been based on models addressed in regional mesoscale grids. The present study represents the first insight into the physical and geochemical coupling mechanisms on the Cabo Frio continental shelf using one-yearlong moored sediment trap experiments. Our data showed that there is no direct relationship between mid-shelf winds and SACW depth on the shelf edge, represented by the $18^{\circ} \mathrm{C}$ isotherm depth in the water column. This fact clearly shows that the middle and outer shelf are not dominated by a winddriven upwelling mechanism that is predominant in the coastal area. Instead, multiple factors act on the shelf to modulate the regional circulation (Belem et al. 2013). These factors include incursions of the internal front of the Brazil Current on the shelf, which were recorded in autumn, when the 


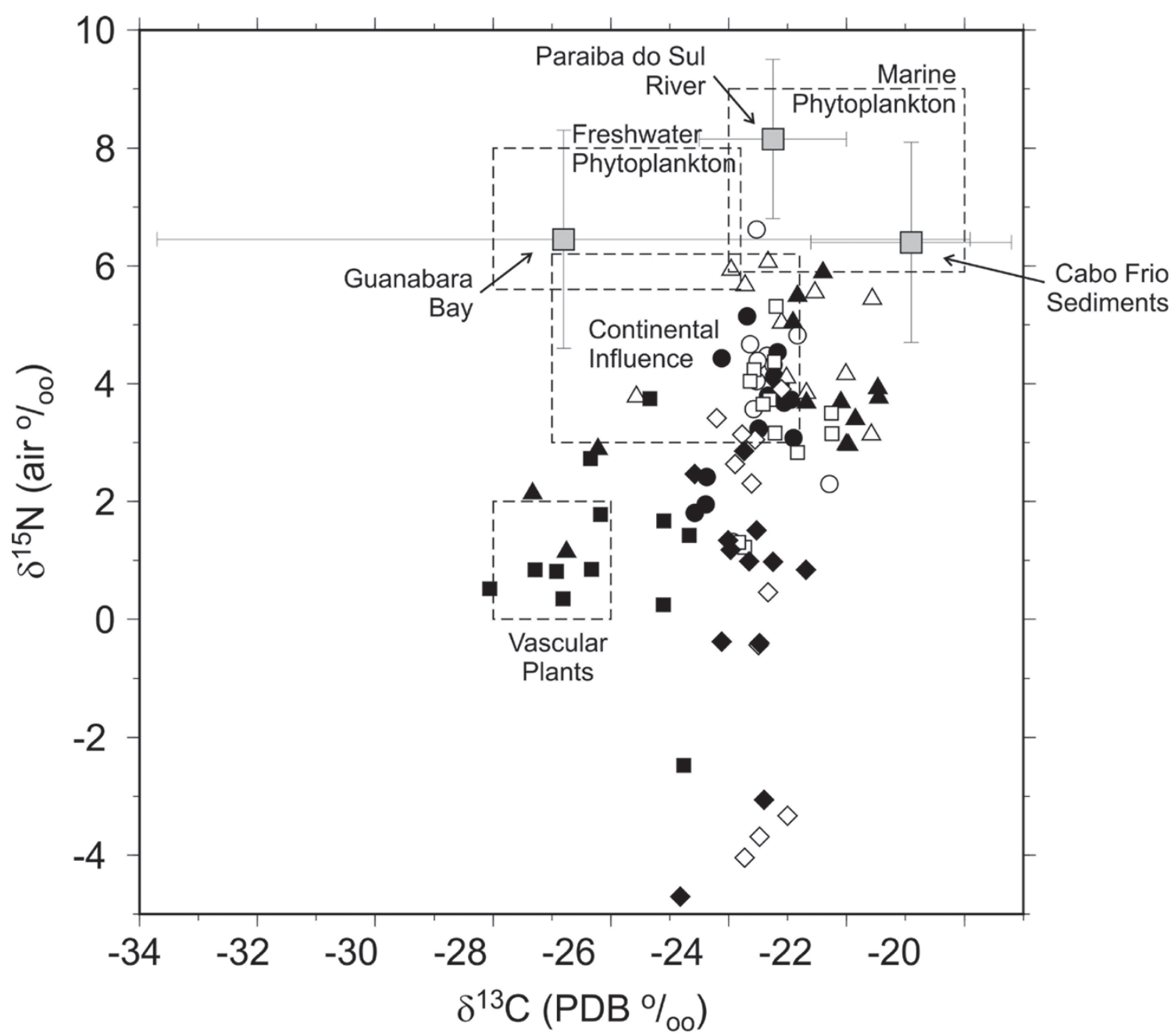

$O \mathrm{I}-50 \mathrm{~m} \bullet \mathrm{I}-100 \mathrm{~m} \quad \Delta \mathrm{II}-50 \mathrm{~m} \Delta \mathrm{II}-100 \mathrm{~m} \quad \square \mathrm{III}-50 \mathrm{~m} \quad \boldsymbol{\mathrm { III }}-100 \mathrm{~m} \diamond \mathrm{IV}-50 \mathrm{~m} \bullet \mathrm{IV}-100 \mathrm{~m}$

Figure 4 - Scatterplot graphic of nitrogen and carbon stable isotopes in organic matter from Cabo Frio trapped particles. Circles, triangles, squares and diamonds represent mooring deployment I (November to December 2010), II (March to June 2011), III (July to September 2011) and IV (December 2011 to February 2012), respectively. Open and closed symbols represent the $50 \mathrm{~m}$ and $100 \mathrm{~m}$ depth sediment traps, respectively. The gray squares in the center of a cross represent the stable isotopic distribution in the Guanabara Bay (Carreira et al. 2002), Paraiba do Sul River (Kahler and Voss 1996) and Cabo Frio bottom sediments (Mahiques et al. 2005).

sea surface temperature reached up to $24^{\circ} \mathrm{C}$. The regional hydrodynamic complexity was indicated by the high frequency of the variability in the depth of the $18^{\circ} \mathrm{C}$ isotherm, as recorded in the mooring experiments. No clear seasonal variability was observed; however, abrupt downwelling events were more frequent during the summer. Most of the time, the $18^{\circ} \mathrm{C}$ isotherm was inside the euphotic zone, indicating that although there is no upwelling on the shelf-edge, frequent SACW intrusions on the euphotic layer might support relevant middle and outer shelf productivity.

Organic carbon represented only a small fraction of particulate fluxes caught in both sediment traps. An undefined mixture of lithogenic, carbonate and biogenic silica particles represented more than $75 \%$ 
of the trapped materials. Although both sediment traps recorded different degrees of marine and land-derived materials, the upper sediment trap was more sensitive to the variability in local physical conditions, suggesting a predominance of local marine phytoplankton-derived organic material. In contrast, the bulk geochemical parameters in the lower sediment trap consistently indicated a relevant contribution of long-distance-transported land-derived material to the organic fraction. The particulate matter settling in the Cabo Frio shelf area seems to be derived from multiple marine and terrestrial sources. Both the Paraiba do Sul River and the Guanabara Bay are potential land sources. Regardless, the material was subjected to an intense transformation (diagenesis) during its trajectory to the shelf edge. Finally, despite the fact that there is no clear seasonal pattern for the flux variability, the timing and magnitude of the peaks allow us to recognize two physical-geochemical coupling conditions: one marked by the correlation between the upward displacement of $18^{\circ} \mathrm{C}$ isotherm and fluxes, which occurred mainly during spring and summer, and the other marked by the decoupling between these physical factors, which was observed during autumn and winter.

Due to the high-frequency variability observed in the physical oceanography scenario, reflected by the thermal oscillations of the water column as well as by the complexity produced by multiple interactions between the oceanographic forcing and geochemical processes, major questions about the main drivers of particulate fluxes and sources remain. Only through long-term monitoring studies can these important issues, such as the role of climatic changes on the regional particulate fluxes and their impact on primary productivity, be addressed.

\section{ACKNOWLEDGMENTS}

The Cabo Frio Upwelling System mooring program would not have been successful without the Projeto Ressurgência team, especially graduate students Igor M. Venancio, Thiago P. Santos, Manuel Botero, Gabrielle R. Faria and Rodrigo P. Ramos, and technicians Whertz Salles and Wladimir Cardoso, who helped with mooring operations and sample handling in the laboratory. We are also especially grateful to the anonymous reviewers for their valuable comments, which strengthened the manuscript. Finally, this project was financially supported by the Geochemistry Network from PETROBRAS/CENPES and by the National Petroleum Agency (ANP) of Brazil (Grant 0050.004388.08.9). A.L.S Albuquerque and B.A. Knoppers are senior scholars from Conselho Nacional de Desenvolvimento Científico e Tecnológico (CNPq).

\section{RESUMO}

Processos físicos e biogeoquímicos em plataformas continentais agem sinergicamente, tanto transportando, quanto transformando o material em suspensão, enquanto a dinâmica do oceano controla a dispersão destas partículas pela zona costeira e sua posterior mistura na plataforma continental. $\mathrm{O}$ sistema de ressurgência de Cabo Frio, localizado na região Sudeste do Brasil, se caracteriza por ser um região de alta produtividade sob a influência da Corrente do Brasil, uma corrente de contorno oeste oligotrófica, mas também com uma zona de ressurgência costeira induzida pelo vento, o que produz as intrusões das águas frias e ricas em nutrientes da Água Central do Atlântico Sul sob a plataforma. Visando entender as interações sinergéticas entre os processos físicos e biogeoquímicos neste sistema, uma série de quatro experimentos com armadilhas de sedimentos e outros sensores físicos foram fundeados na isóbata de 145 metros, no período entre novembro de 2010 e março de 2012. Um total de 98 amostras discretas foram analisadas. Os resultados mostraram que o transporte lateral pode ser importante em alguns casos, especialmente nas camadas mais profundas. Embora não tenha sido detectado nenhum ciclo sazonal claro, dois cenários de acoplamento físicogeoquímicos foram identificados: eventos de subsidência que produzem um aumento nos fluxos de partículas e são 
potencialmente relacionados às oscilações da Corrente do Brasil; e eventos de fluxos significativos relacionados com a intrusão da isoterma de $18^{\circ} \mathrm{C}$ na zona eufótica. As partículas em suspensão na plataforma continental de Cabo Frio representam uma mistura de fontes marinhas e continentais. Tanto o Rio Paraíba do Sul quanto a Baía de Guanabara podem ser potenciais fontes continentais, embora o material particulado possa ainda estar sujeito a intensa transformação (diagênese) durante sua trajetória para a borda da plataforma continental.

Palavras-chave: armadilhas de sedimentos, geoquímica do particulado, Sistema de Ressurgência de Cabo Frio, fluxo de partículas, Plataforma continental do Sudeste do Brasil.

\section{REFERENCES}

Aguiñga S, Sanchez A And Silverberg N. 2010. Temporal variations of $\mathrm{C}, \mathrm{N}, \delta 13 \mathrm{C}$, and $\delta 15 \mathrm{~N}$ in organic matter collected by a sediment trap at Cuenca Alfonso, Bahía de La Paz, SW Gulf of California. Cont Shelf Res 30: 16921700.

Aidar E, Gaeta SA, Gianesella-Galvão SMF, Kutner MBB AND TEIXEIRA C. 1993. Ecossistema costeiro tropical: nutrientes dissolvidos, fitoplâncton e clorofila-a, e suas relações com as condições oceanográficas na região de Ubatuba. Publ Esp Inst Oceanogr 10: 9-43.

Alt-Epping U, Mil-Homens M, HebBeln D, Abrantes F AND SCHNEIDER RR. 2007. Provenance of organic matter and nutrient conditions on a river- and upwelling influenced shelf: A case study from the Portuguese Margin. Mar Geol 243: 169-179.

ARMstrong RA, LeE C, Hedges JI, Honjo S AND WAKeHAM SG. 2001. A new, mechanistic model for organic carbon fluxes in the ocean based on the quantitative association of POC with ballast minerals. Deep-Sea Res Pt II 49: 219-236.

Belem A, Castelao R and Albuquerque AL. 2013. Controls of subsurface temperature variability in a western boundary upwelling system. Geophys Res Lett 40: 1362-1366.

BRANDINI FP. 1990. Hydrography and characteristics of the phytoplankton in shelf and oceanic waters off southeastern Brazil during winter (July/August 1982) and summer (February/ March 1984). Hydrobiologia 196: 111-148.

Calado L, Gangopadhyay A AND Silveira ICA. 2008. Feature-oriented regional modeling and simulations (FORMS) for the western South Atlantic: Southeastern Brazil region. Ocean Model 5: 48-64.

Calado L, Silveira ICA, Gangopadhyay A and Castro BM. 2010. Eddy-induced upwelling off Cape São Tomé (22 ${ }^{\circ} \mathrm{S}$, Brazil). Cont Shelf Res 30: 1181-1188.
CAmpos EJD, Velhote D AND Silveira ICA. 2000. Shelf break upwelling driven by Brazil Current Cyclonic Meanders. Geophys Res Lett 27: 751-754.

CARBOnEL C. 2003. Modelling of upwelling-downwelling cycles caused by variable wind in a very sensitive coastal system. Cont Shelf Res 23: 1559-1578.

CARreira RS, WAgener ALR, READMAN JW, Fileman TW, Macko SA And VeIgA Á. 2002. Changes in the sedimentary organic carbon pool of a fertilized tropical estuary, Guanabara Bay, Brazil: an elemental, isotopic and molecular marker approach. Mar Chem 79: 207-227.

CASTELAO RM. 2012. Sea surface temperature and wind stress curl variability near a cape. J Phys Oceanogr 42: 2073-2087.

CASTELAO RM AND BARTH JA. 2006. Upwelling around Cabo Frio, Brazil: The importance of wind stress curl. Geophys Res Lett 33: 2-5.

CAstro BM, Miranda LB AND MiYaO SY. 1987. Condições hidrográficas na plataforma continental ao largo de Ubatuba: variações sazonais e em média escala. Bol Inst Oceanogr 35: 135-151.

Castro B, Miranda LB, Silva LS, Fontes RFC, Pereira AF And Coelho A. 2008. Processos Físicos: Hidrografia, Circulação e Transporte. In: Pires-Vanin AMS (Ed), Oceanografia de um Ecossistema Subtropical: Plataforma de São Sebastião, SP, São Paulo: Editora da Universidade de São Paulo, p. 59-121.

Franchito SH, OdA TO, RAO VB AND KAYANO MT. 2008. Interaction between coastal upwelling and local winds at Cabo Frio, Brazil: an observational study. J Appl Meteorol Climatol 47: 1590-1598.

Franchito SH, RaO VB, STECH JL AND LORENZZETI JA. 1998. The effect of coastal upwelling on the sea-breeze circulation at Cabo Frio, Brazil: a numerical experiment. Ann Geophys 16: 866-881.

GONZALEZ-RODRIGUEZ E, VALENTIN JL, ANDRÉ DL AND JACOB SA. 1992. Upwelling and downwelling at Cabo Frio (Brazil): comparison of biomass and primary production responses. J Plankton Res 14: 289-306.

GoswAMI SC. 2004. Zooplankton. Methodology, Collection \& Identification a field manual, $1^{\text {st }}$ ed., Goa: National Institute of Oceanography, $26 \mathrm{p}$.

GrasshofF K, KREMLING K AND EhraRdT M. 1999. Methods of Seawater Analysis. $3^{\text {rd }}$ ed., New York, Chichester, Brisbane, Singapore, Toronto, Weinheim: Wiley-VCH, 634 p.

HASTINGS MG, SigMAN DM AND LiPSCHULTZ F. 2003. Isotopic evidence for source changes of nitrate in rain at Bermuda. J Geophys Res 108: 1-12.

HedGES JI AND OAdES JM. 1997. Comparative organic geochemistries of soils and marine sediments. Org Geochem 27: 319-361.

Honjo S, Manganini S, KRISHFiEld R AND Francois R. 2008. Particulate organic carbon fluxes to the ocean interior and factors controlling the biological pump: A synthesis of global sediment trap programs since 1983. Prog Oceanogr 76: $217-285$. 
JASPER J AND GAGOSIAN R. 1990. The sources and deposition of organic matter in the Late Quaternary Pigmy Basin, Gulf of Mexico. Geochim Cosmochim Acta 54: 1117-1132.

JENNERJAHN T AND ITTEKKOT V. 1999. Changes in organic matter from surface waters to continental slope sediments off the Sao Francisco River, eastern Brazil. Mar Geol 161: 129-140.

JENNERJAHN T, ITTEKKOT V, CARVALHO C, OVALLE A, REZENDE C AND ERLENKKEUSER H. 1999. Temporal variability of amino acid, hexosamine, and carbohydrate fluxes on the eastern Brazilian continental margin related to discharge of the Sao Francisco River. Geo-Mar Lett 19: 202-208.

Jennerjahn T, Knoppers A, De Sousa W, Carvalho C, Mollanhaue G, Hubner M and ItTeKKot V. 2010. The tropical Brazilian continental margin. In: Liu K et al. (Eds), Carbon and Nutrient Fluxes in Continental Margins, A global synthesis, Berlin: Springer Verlag Heidelberg, p. 427-436.

KAHLER P AND VosS M. 1996. The isotopic composition of particular organic matter in the Rio Paraiba. In: Ekau W and Knoppers B (Eds), Joint Oceanographic Projects JOPS-II, cruise report and first results - Sedimentation processes and productivity in the continental shelf waters off East and Northeast Brazil, Bremen: Center for Tropical Marine Ecology, 15 p.

KNAPP AN, HASTINGS MG, SigMan DM, LiPSCHULTZ F AND GALLOWAY JN. 2010. The flux and isotopic composition of reduced and total nitrogen in Bermuda rain. Mar Chem 120: 83-89.

KNopPers B, CARneiro M, Mendoza U AND BALZER W. 1996 Nutrients and suspended matter. In: Ekau W and knoppers B (Eds), Joint Oceanographic Projects JOPS-II, cruise report and first results - Sedimentation processes and productivity in the continental shelf waters off East and Northeast Brazil, Bremen: Center for Tropical Marine Ecology, 12 p.

KNOPPERS B AND MOREIRA PF. 1990. Matéria em suspensão e a sucessão do Fitoplâncton na lagoa de Guarapi-Na, ES. Acta Limnol Bras 3: 291-317.

LiU KK, ATKINSON L, QUiÑONES R AND TALAUE-MCMANUS L. 2010. Biogeochemistry of Continental Margins in a Global Context. In: Liu KK, Atkinson L, Quiñones R and Talaue-McManus L (Eds), Carbon and Nutrient Fluxes in Continental Margins. A global synthesis, Berlin: Springer Verlag Heidelberg, p. 3-24.

LIU KK AND KAPLAN IR. 1989. The eastern tropical Pacific as a source of $15 \mathrm{~N}$ - enriched nitrate in seawater off southern California. Limnol Oceanogr 34: 820-830.

Lopes RM, KatsuragawaM, Dias JF, Montu MA, Muelbert JH, GORRI C AND BRANDINI FP. 2006. Zooplankton and ichthyoplankton distribution on the southern Brazilian shelf: An overview. Sci Mar 70: 189-202.

LORENZETTI JA AND GAETA SA. 1996. The Cape Frio upwelling effect over the South Brazil Bight Northern sector shelf waters: a study using AVHRR images. Int Arch Photogramm Remote Sens 31: 448-453.

LORRAIN A. 2003. Decarbonation and preservation method for the analysis of organic $\mathrm{C}$ and $\mathrm{N}$ contents and stable isotope ratios of low-carbonated suspended particulate material. Anal Chim Acta 491: 125-133.
MAHIQUES MM, BÍCEGO MC, SILVEIRA ICA, SOUSA SHM, LOURENÇO R AND MARINA F. 2005. Modern sedimentation in the Cabo Frio upwelling system, Southeastern Brazilian shelf. An Acad Bras Cienc 77: 535-548.

Mahiques MM, Tessler MG, CiotTi AM, Silveira ICA SOUSA SHM, FIGUEIRA RCL, TASSINARI CCG, FURTADO VV AND PASSOS RF. 2004. Hydrodynamically driven patterns ofrecent sedimentation in the shelf and upper slope off Southeast Brazil. Cont Shelf Res 24: 1685-1697.

Mantoura RFC, Martin JM AND Wollast R. 1991. Ocean Margin Processes in Global Change. Dahlem Workshop Reports. Chichester: J Wiley \& Sons, 469 p.

MATSUURA Y. 1996. A probable cause of recruitment failure of Brazilian Sardine (Sardinella aurita) population during the 1974/75 spawning season. S Afr J Mar Sci 17: 29-35.

MEYERS PA AND TERANES JL. 2001. Sediment organic matter In: Last WM and Smol JP (Eds), Tracking Environmental Changes Using Lake Sediment, Vol. 2: Physical and Geochemical Methods, Dordrecht: Kluwer Academic, p. 239-270.

MoreIRA DA Silva PC. 1973. A ressurgência de Cabo Frio. Inst Pesq Mar 78: 1-56.

Morel A, Huot Y, Gentili B, Werdell PJ, HoOKer SB And FRANZ BA. 2007. Examining the consistency of products derived from various ocean color sensors in open ocean (Case 1) waters in the perspective of a multi-sensor approach. Remote Sens Environ 111: 69-88.

O'Brien M, Humfrey M, Petersen TF and Macdonald RW. 2013. The role of eddies on particle flux in the Canada Basin of the Arctic Ocean. Deep-Sea Res Pt I 71: 1-20.

Ogrinc N, Fontolan G, Faganeli J and Covelli S. 2005. Carbon and nitrogen isotope compositions of organic matter in coastal marine sediments (the Gulf of Trieste, N Adriatic Sea): indicators of sources and preservation. Mar Chem 95: 163-181.

OLIVEIRA EN, KNOPPERS BA AND LORENZETTI JA. 2012. A Satellite View of Riverine Turbidity Plumes on the NE-E. Braz J Oceanogr 60: 283-298.

O'REILLY JE ET AL. 2000. Ocean color chlorophyll a algorithms for Sea WiFS, OC2, and OC4: version 4. SeaWiFS postlaunch calibration and validation analyses, Part 3 . In: Hooker SB and Firestone ER (Eds), NASA technical memorandum, Greenbelt, Maryland: NASA Goddard Space Flight Center 206892, p. 9-23.

Pereira AF AND CASTRO BM. 2007. Internal Tides in the Southwestern Atlantic off Brazil: Observations and Numerical Modeling. J Phys Oceanogr 37: 1512-1526.

ROBINSON RS ET AL. 2012. A review of nitrogen isotopic alteration in marine sediments. Paleoceanography 27: PA4203.

RODRIGUES RR AND LORENZETTI JA. 2001. A numerical study of the effects of bottom topography and coastline geometry on the Southeast Brazilian coastal upwelling. Cont Shelf Res 21: 371-394.

SAlOMÃo MSM, Molisani MM, OVAlle ARC, REZENDE CE, LACERDA LD AND CARVALHo CEV. 2001. Particulate heavy metal transport in the lower Paraíba do Sul River basin, southeastern, Brazil. Hydrol Process 15: 587-593. 
SAMPAIO L, Rodrigues AM AND QUINTINO V. 2010. Carbon and nitrogen stable isotopes in coastal benthic populations under multiple organic enrichment sources. Mar Pollut Bull 60: 1790-1802.

SCHMIDT F, HINRICHS KU AND ElEVERT M. 2010. Sources, transport, and partitioning of organic matter at a highly dynamic continental margin. Mar Chem 118: 37-55.

Shang S, LeE ZAnd Wei G. 2011. Characterization of MODISderived euphotic zone depth: Results for the China Sea. Remote Sens of Environ 115: 180-186.

Sigman DM, Alatabet MA, McCorkle DC, Francois R AND FISCHER G. 2000. The $\delta^{15} \mathrm{~N}$ of nitrate in the Southern Ocean: nitrogen cycling and circulation in the interior ocean. J Geophys Res 105: 599-614.

Silveira ICA, Lima JAM, SCHMIdT ACK, CeCCOPIERIB W, SARTORI A, FRANCISCO CPF AND FONTES RFC. 2008. Is the meander growth in the Brazil Current system off Southeast Brazil due to baroclinic instability? Dynam Atmos Oceans 45: 187-207.

Silverberg N, Aguirre F, Aguiñiga S And Romero N. 2006. Flujo vertical de materia particulada en la Cuenca Alfonso, Bahía de La Paz, durante 2002. Cienc Mar 32: $73-82$.

SilverberG N AND BAHENA F. 2007. Flujos verticales de carbono orgánico e inorgánico particulado en Cuenca Alfonso, Bahía de La Paz, y comparación con otros ambientes en el norte de México. In: Torre BBH and Castro GG (Eds), Carbono en ecosistemas acuáticos de México. Mexico: Centro de Investigación Científica y de Educación Superior de Ensenada-Instituto Nacional de Ecología, p. 411-426.
Tesi T, Miserocchi S, GoÑI MA, LANgone L, Boldrin A AND TURCHETTO M. 2007. Organic matter origin and distribution in suspended particulate materials and surficial sediments from the western Adriatic Sea (Italy). Estuar Coast Shelf Sci 73: 431-446.

THUNELL RC. 1998. Particle fluxes in a coastal upwelling zone: sediment trap results from Santa Barbara Basin, California. Deep-Sea Res Pt II 45: 1863-1884.

TURner A AND Millward GE. 2002. Suspended particles: their role in estuarine biogeochemical cycles. Estuar Coast Shelf Sci 55: 857-883.

VALENTIN JL, ANDRE DL, MONTEIRO WM AND TENENBAum DR. 1978. Hidrologia e plâncton da região costeira entre Cabo Frio e o estuário do Rio Paraiba (BRASIL). Inst Pesq Mar 127: 1-24.

VALENTIN JL AND KEMPF M. 1977. Some characteristics of the Cabo Frio Upwelling (Brazil). Coast Upwelling Ecosyst Analysis News1 6: 18-21.

VALENTIN JL. 1984. Analyse des paramètres hydrobiologiques dans la remontée de Cabo Frio (Brésil). Mar Biol 82: 259-276. 